\title{
PENGELOLAAN DATA PRODUKSI BERBASIS WEB PADA CV. SUMBER PROTEINA BANDAR LAMPUNG
}

\author{
TM Zaini ${ }^{1}$, Driya Wiryawan ${ }^{2}$, Aryadi $^{3}$ \\ ${ }^{\mathbf{1 , 3}}$ Fakultas Ilmu Komputer, Institut Informatika \& Bisnis Darmajaya \\ J1. Z.A Pagar Alam No 93, Bandar Lampung - Indonesia 35142 \\ Telp. (0721) 787214 Fax. (0721)700261. \\ ${ }^{2}$ Fakultas Ekonomi dan Bisnis Universitas Lampung \\ Jl. Prof. Brojonegoro No.1. Gedung Meneng Bandar Lampung - Indonesia 35141 \\ e-mail : tmzaini@darmajaya.ac.id, driyawiryawan@gmail.com \\ aryadi_97e@yahoo.com
}

\begin{abstract}
$C V$. Sumber Proteina is a company that engaged in animal husbandry that produces and distributes chicken eggs. The reporting process at this company is still done manually, so it takes quite a long time to be able to provide reporting data until it reaches the head office. Thus the report need long time to reach the manager. Based on this, this company need a website that can facilitate the delivery of reports and data processing reports, so as to minimize the time of sending data and managing data reports. Management of production data at this company can help decision-making parties at the management level to speed up the process of reporting and processing production data. The system development uses the RAD (Rapid Application Development) model and the design tool is the Unified Modeling Language (UML). The stages for developing RAD system begin at the planning requirements stage, the user design, the Rapid Construction stage and the cutover or system testing stage. The results of this study are in the form of a system that can provide information on the availability of chicken eggs and can also be used online for consumers.
\end{abstract}

Keywords-Data Processing, Production, Report, Website.

\begin{abstract}
ABSTRAK
Perusahaan CV. Sumber Proteina adalah perusahaan yang bergerak dibidang peternakan yang memproduksi sekaligus sebagai distributor telur ayam. Proses pelaporan pada perusaan ini masih dilakukan secara manual sehingga membutuhkan waktu yang cukup lama untuk dapat memberikan data pelaporannya hingga sampai di kantor pusat. Dengan demikian mengakibatkan lambatnya informasi untuk sampai ke manager. Berdasarkan hal tersebut maka dibutuhkan sebuah website yang dapat memudahkan pengiriman laporan dan pengolahan data laporan, sehingga dapat meminimalisir waktu pengiriman data dan pengelolaan data laporan. Pengelolaan data produksi pada perusahaan ini dapat membantu pihak pengambilan keputusan di tingkatan manajemen guna mempercepat proses pelaporan dan pengolahan data produksi. Pengembangan sistem menggunakan model RAD (Rapid Application
\end{abstract}


Development) dan sebagai tool perancangannya adalah Unified Modelling Language $(U M L)$. Tahapan untuk pengembangan sistem RAD ini diawali dengan tahap planning requirement, tahap user design dan workshop, tahap Rapid Construction dan cutover atau tahap pengujian sistem. Hasil penelitian ini berupa sistem yang dapat memberikan informasi data ketersediaan telur ayam sekaligus dapat dimanfaat bagi konsumen secara online.

Kata kunci-Pengolahan Data, Produksi, Pelaporan, Website.

\section{PENDAHULUAN}

Perkembangan teknologi saat ini telah berdampak terhadap pekerjaan, karena mempermudah suatu pekerjaan. Keberadaan teknologi yang berkembang dengan cepatnya adalah teknologi komunikasi yang meliputi hardware seperti komputer dan peralatan elektronik yang semakin banyak diminati oleh pengguna dimana pengembang dapat lebih menekankan pada studi kelayakan dan definisi sistem. [1] Teknologi Informasi telah merambah dan diterapkan di berbagai bidang antara lain bidang produksi dan peternakan. Kebutuhan akan pengolahan data dan pelaporan, merupakan masalah yang penting dalam manajemen sebuah perusahaan. Salah satunya adalah CV. Sumber Proteina yang merupakan suatu perusahaan yang bergerak dibidang peternakan dengan memproduksi telur ayam, pendistribusian telur ayam dan pembesaran ayam.
Adapun pengiriman laporan dilakukan oleh seorang kurir telur dan kemudian melakukan pengiriman pada waktu pagi hari di mana telah di kumpulkan telur-telur yang siap untuk dikirimkan, sedangkan keterlambatan proses laporan pada produksi telur untuk dapat disampaikan pada kantor pusat serta terhambatnya informasi untuk sampai kepada seorang manager, maka untuk itu diperlukan pemecahan masalah guna mempercepat pengelolaan data produksi dan data pelaporan.

Solusi yang ditawarkan adalah mengembangkan, Pengelolaan Data Produksi pada CV. Sumber Proteina ini yaitu kiranya dapat membantu pihak manajemen perusahaan untuk dapat mempercepat proses pelaporan data produksi dan pengolahan data produksi. Dengan adanya pengelolaan data produksi ini selanjutnya akan memudahkan proses pengolahan data dan pelaporan. Sebagai contoh, karyawan CV. Sumber Proteina hanya perlu login 
ke website selanjutnya melakukan input data produksi, kemudian website akan mengolah data produksi, begitupun manager hanya perlu login ke website untuk melihat laporan produksi.

Website ini dapat terjemahkan sebagai suatu kumpulan halaman yang menampilkan informasi data teks, gambar diam atau bergerak, data animasi, suara, video serta gabungannya, baik yang bersifat tetap maupun dinamis yang membentuk suatu kesatuan bangunan yang saling terhubung dimana setiap unit disatukan dengan jaringan halaman (hyperlink) [2]

Informasi merupakan data dihasilkan dari proses pembentukan yang lebih bermanfaat dan lebih berarti bagi penggunanya.[3]

Proses pengolahan basis data yang terdistribusi merupakan suatu proses dimana kegiatan aktivitas transaksi, pengambilan dan pemuktahiran data yang terjadi telah melalui dua atau lebih perangkat komputer yang umumnya terpisah letaknya dan tidak saling terhubung. [4]

\section{METODE PENELITIAN}

Metode yang digunakan dalam penelitian ini adalah pengembangan aplikasi menggunakan metode Rapid Aplication Development (RAD)., yang dilakukan dengan menerapkan empat tahapan untuk pengembangan sistem informasi CV. Sumber Proteina, yaitu:

\section{Planning Requuirement.}

Pada tahap ini dilakukan pengumpulan data-data dan informasi mengenai gambaran umum, wawancara dan identifikasi tugas pokok pada bagian produksi CV. Sumber Proteina Bandar Lampung.

\section{User Design.}

Pada tahapanan ini dilakukan proses desain pada sistem yang di kembangkan dan kebutuhan sistem serta usulan pada sistem berbasis web. untuk CV. Sumber Proteina Bandar Lampung.

Adapun penggunaan tahapan analisis dan desain Object Oriented Programming [5] yaitu: (a). Komunikasi Pada tahap komunikasi mengestimasi kebutuhan sistem baru yang akan dikembangkan. Analisis di mulai dari pengumpulan data terkait produksi pada CV. Sumber Proteina Bandar Lampung, yang dilakukan dengan beberapa metode pengumpulan data yang telah dijabarkan diatas dan juga melakukan konsulasi dengan pelanggan/stakeholder.

Perencanaan secara cepat (quick plan). Tahap ini lebih menekankan pada tahap 
desain sistem secara cepat, desain sistem dilakukan untuk menindak lanjuti tahap sebelumnya dan sebagai acuan pembuatan program. Pada fase ini penulis melakukan perancangan arsitektur menggunakan Unified Modeling Language ( UML) dimana bahasa pemodelan ini merupakan sistem yang menerapkan konsep pemrograman berorientasi pada objek yang melakukan analisa serta menjabarkan secara detail yang diperlukan sistem.[6] Rancangan yang dibuat berupa diagram sebagai berikut: Document Flowchart, UseCase, Class Diagram dan Sequence Diagram. (c) Pembuatan Model (Modeling Quick Design), Pada tahap ini mentranslasikan dari desain yang telah dirancang ke pemodelan (modeling) dimana dilakukan pembuatan desain sistem (Design User Interface). (d) Konstruksi Prototipe (Construction of Prototype), Tahapan ini adalah tahapan yang membangun sistem berdasarkan desain sistem (Design User Interface) sebelumnya dimana pada tahapan ini dilakukan pengkodeanpengkodean yang menggunakan bahasa pemrograman. (e) Penyerahan sistem (Deployment Delivery \& Feedback). Tahap ini adalah merupakan tahapan serah terima dari sistem yang telah dibuat kepada CV. Sumber Proteina Bandar
Lampung. Umpan balik akan terjadi saat perawatan sistem, umpan balik berupa peluasan sistem dan pemahanam tentang umpan balik selanjutnya. Pada tahap ini tim pengembang menyerahkan sistem kepada CV. Sumber Proteina Bandar Lampung .

\section{Rapid Construction}

Dalam tahapan ini pengujian dilakukan pada tingkatan pengguna (user) dari sistem informasi CV. Sumber Proteina, agar dapat diketahui pemahaman terhadap sistem informasi yang dikembangkan.

\section{Cutover}

Pada tahapan ini dilakukan pengujian dengan cara menguji setiap fungsi-fungsi, dimana fungsi-fungsi tersebut akan diuji kesesuainya dengan hasil yang diharapkan. Pengujian ini biasanya dilakukan berdasarkan spesifikasi yang dianalisa secara informal dan manual. [7]

\section{HASIL DAN PEMBAHASAN}

Pada tahap analisa sistem ini dilakukan analisis dari sistem yang sudah berjalan pada bagian produksi perusahaan $\mathrm{CV}$. Sumber Proteina Bandar Lampung untuk mengetahui alur proses yang berjalan secara terinci digunakan Document 
Flowchart seperti yang terlihat pada gambar 1.

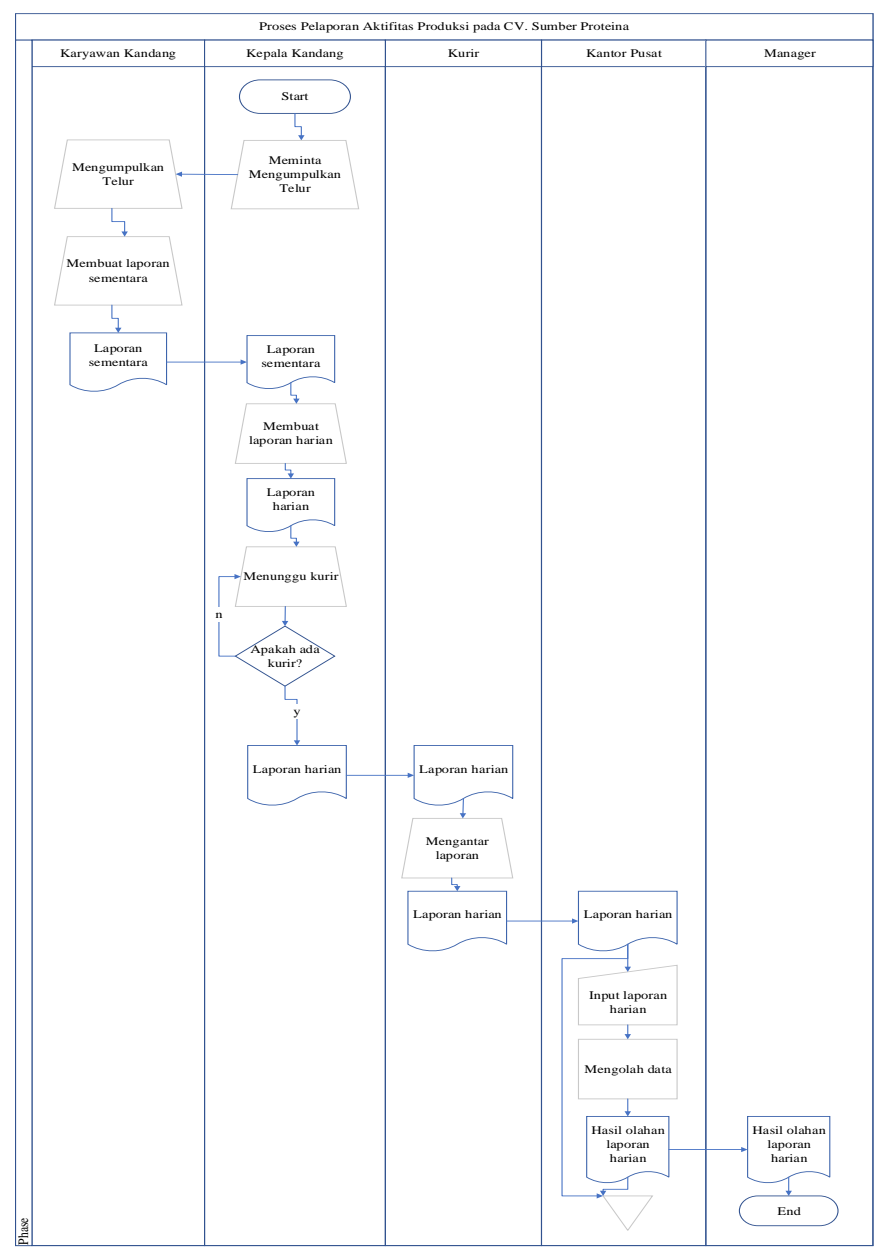

b. Dalam pengiriman laporan terkendala oleh ada atau tidaknya kurir yang akan mengirim telur.

c. Laporan produksi telur hanya dapat dilaporkan paling banyak satu kali dalam sehari.

d. Administrasi memerlukan waktu yang cukup lama untuk mengolah data produksi.

Setelah diketahui permasalahan yang terjadi pada tahap analisis sistem, maka tahap selanjutnya adalah menganalisis alternatif tindakan yang biasa dilakukan. Desain sistem yang akan dibuat meliputi: Use case, Class Diagram, dan Sequence Diagram. Gambar 2 memperlihatkan aktor yang terlibat dalam system informasi ini, yaitu: Karyawan kandang, Admin, Manager dan user (customer), serta aksi yang dapat dilakukan oleh masing-masing aktor.

\section{Gambar 1. Document Flowchart}

Sistem Informasi yang berjalan.

Dari hasil Analisa dari proses pelaporan produksi yang berjalan di CV. Sumber Proteina, ditemukan beberapa masalahk, yaitu :

a. Kepala kandang memerlukan waktu yang cukup lama untuk membuat laporan.

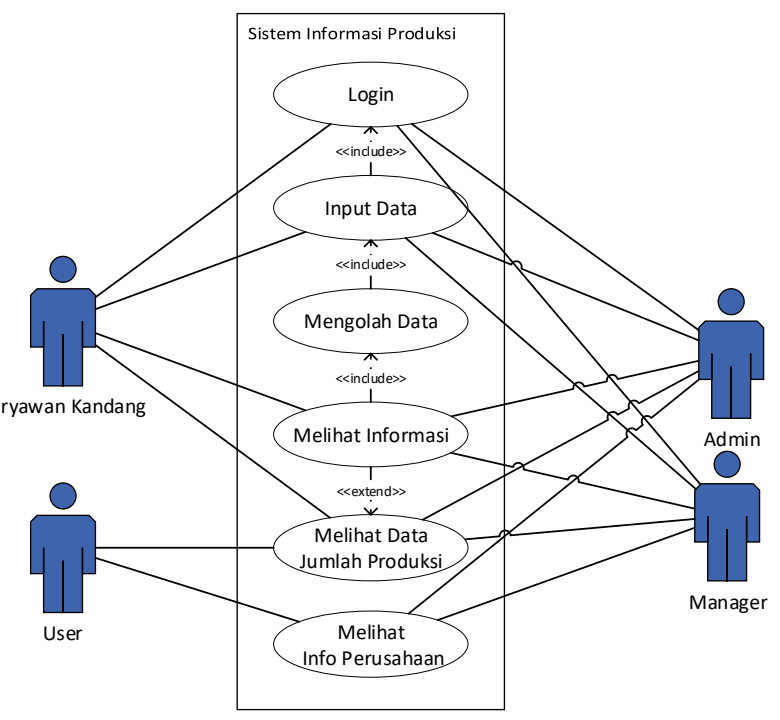

Gambar 2. Use Case yang diusulkan 
Adapun Class diagram ditunjukkan pada gambar 3, yang menjelaskan kelas-kelas yang terdapat pada sitem informasi ini yaitu sebanyak Sembilan kelas yaitu: Ayam, Produksi, Transaksi, Barang, Kandang, Obat, Karyawan, Pesan, Data Kandang dan Admin.
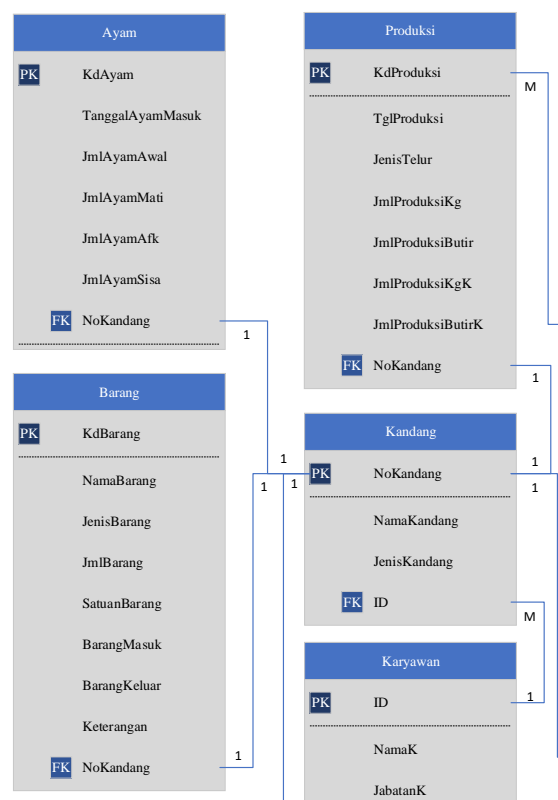

FK NoKandang
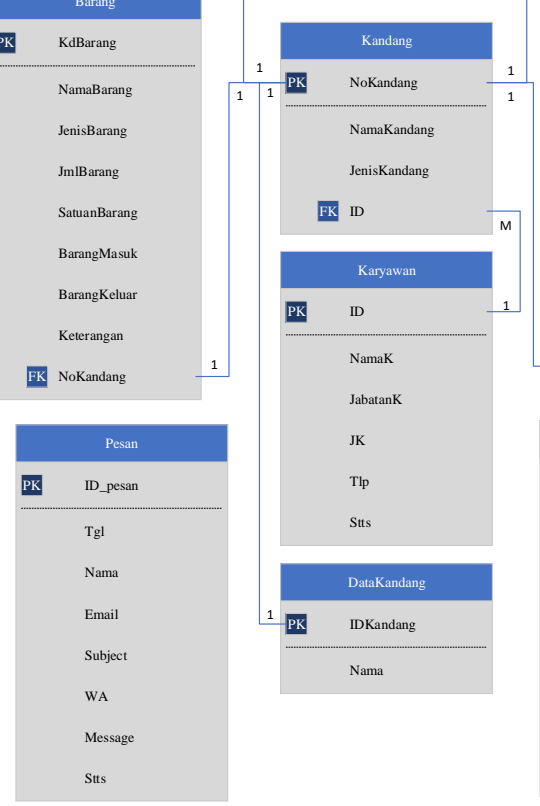

Gambar 3. Class Diagram

Sedangkan Sequence diagram untuk proses login ditunjukkan pada gambar 4 .

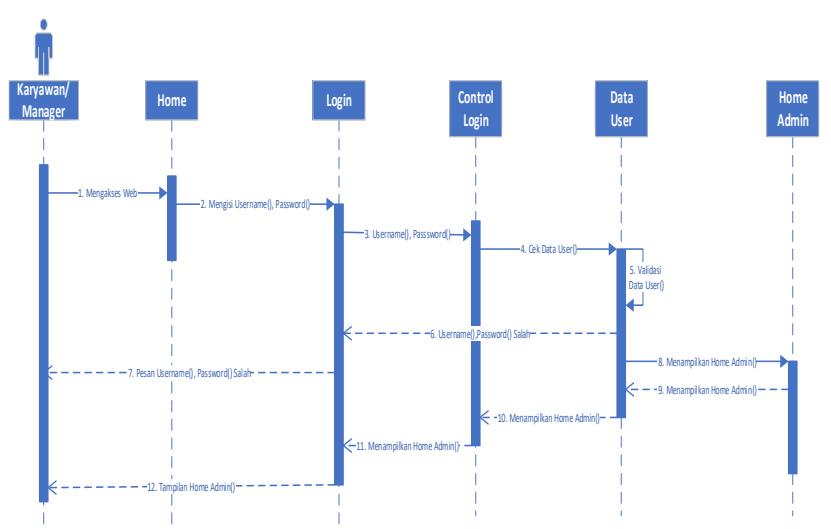

Gambar 4. Sequence Diagram login

Untuk Sequence diagram untuk input ditunjukkan pada gambar 5. Karyawan atau manager dapat memasukan data melalui menu input data, setelah data divalidasi selanjutnya data akan tersimpan pada database.

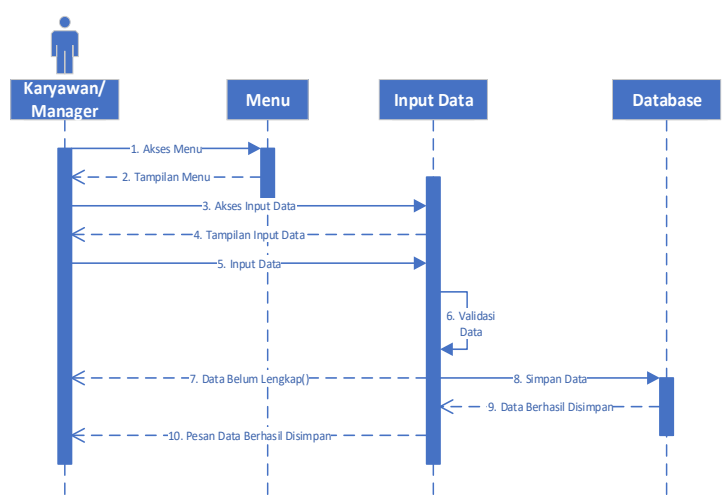

Gambar 5. Sequence Diagram Input

Adapun Sequence diagram untuk proses Cek Data ditunjukkan pada gambar 6 . Pada proses ini, karyawan atau manager dapat memeriksa data yang terdapat pada table data. 

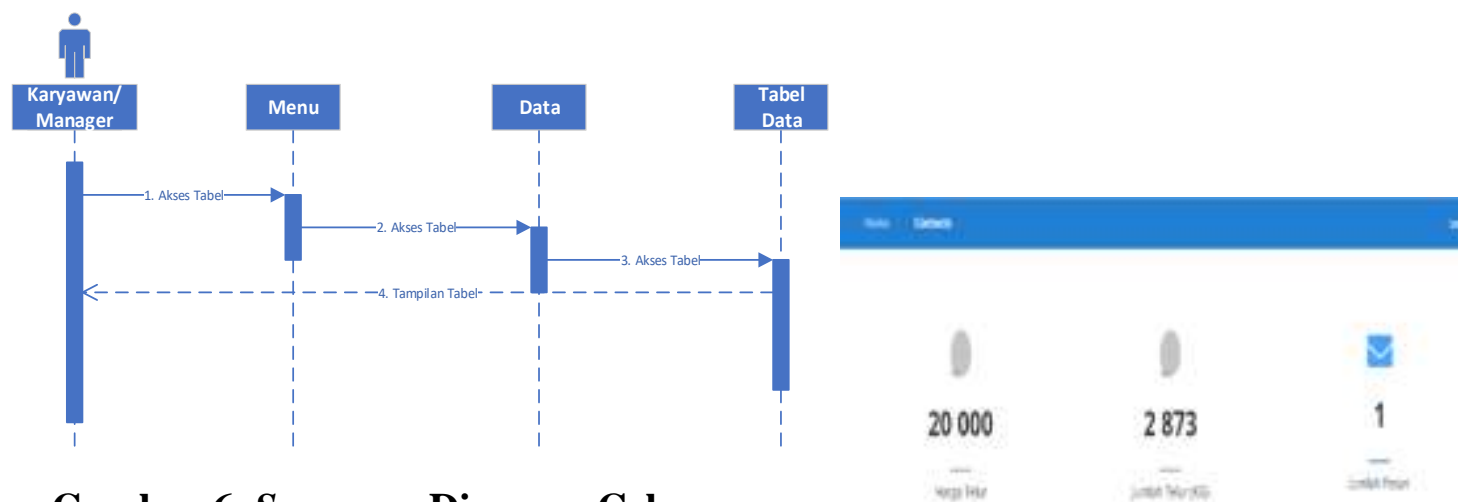

Gambar 6. Sequence Diagram Cek

Data

Pengelolaan Data Produksi

Berbasis Web pada CV. Sumber Proteina Bandar Lampung, memiliki beberapa Gambar 8. Halaman Info Produksi menu dan halaman informasi, gambar 7 memperlihatkan tampilan awal atau home yang ada pada aplikasi ini.

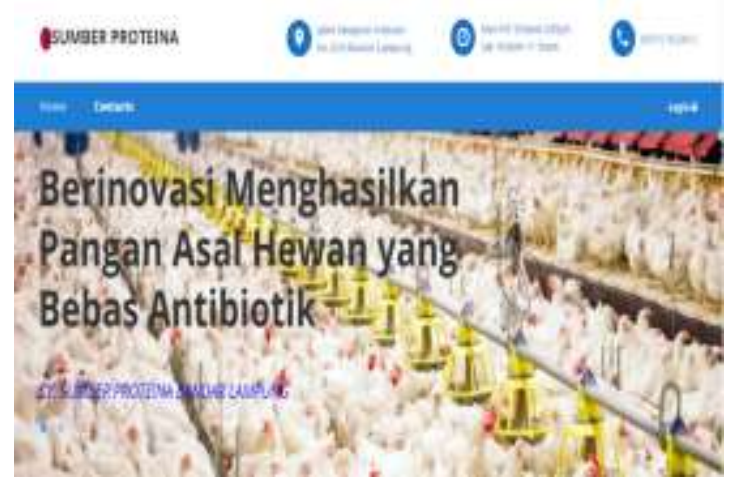

Adapun Input Data Harian dilakukan dengan memasukan data produksi berdasarkan dari token yang telah diinput-kan sebelumnya yang ditunjukkan pada gambar 9. Pada form input data harian ini, petugas kandang dapat memasukan data secara real-time.

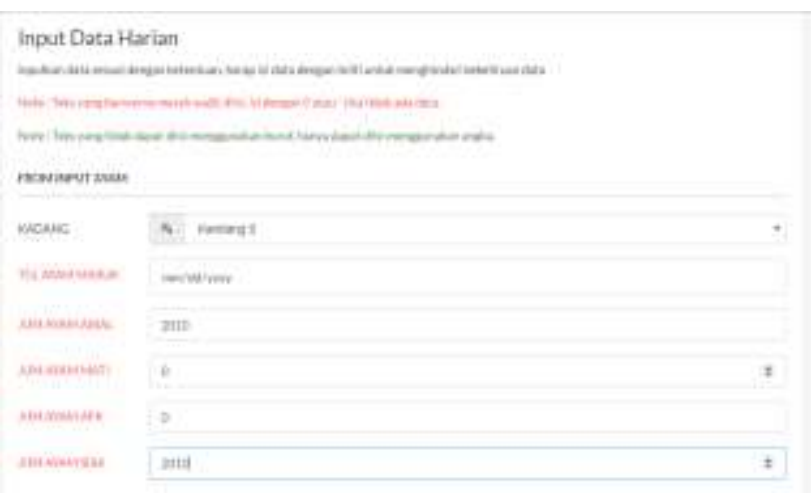

Gambar 7. Tampilan Home

Untuk halaman info produksi ditunjukkan pada

Gambar 9. Menu Input Data Produksi

gambar 8, pengguna dapat melihat informasi harga telur, jumlah telur dan jumlah pesan.

Adapun Laporan Harian yang menunjukkan tentang Kandang, Jumlah 
Hewan Ternak Awal, Jumlah Hewan ternak mati, afkir dan jumlah hewan yang hidup perhari serta jumlah butir telur harian, berat telur setiap kilo per harinya $(\mathrm{KG})$, berat ayam per Gramnya setiap ekor $(\mathrm{G} / \mathrm{EKOR})$ dan berat telur setiap gramnya per butir (G/BTR) ditunjukkan pada gambar 10. Laporan yang diproses oleh sistem informasi ini sangat membantu kelancaran operasional dari CV. Sumber Proteina.

3. Terdapat 2 level user yaitu admin dan manager.

4. Menyebarkan informasi tentang harga telur dan produksi telur yang tersedia pada masyarakat.

5. Masyarakat dapat mengakses halaman website terbatas pada halaman awal (Home).

6. Masyarakat dapat mengirim pesan kepada admin atau manager melalui Menu Contact.

Sedangkan keterbatasan yang terdapat pada Sistem Informasi ini, sebagai

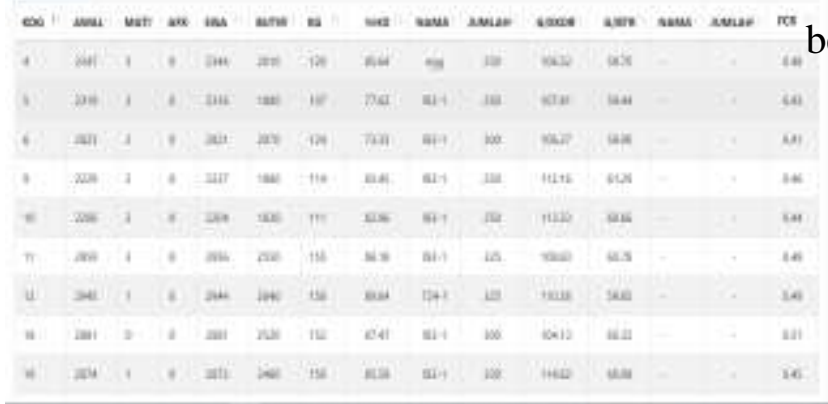

Gambar 10. Data Laporan Harian Produksi

Pengelolaan Data Produksi telur berbasis web ini memiliki beberapa kelebihan dan keterbatasan. Kelebihan sistem informasi ini, sebagai berikut :

1. Mempermudah karyawan dalam membuat laporan produksi.

2. Menghemat waktu yang diperlukan dalam pengiriman laporan produksi.
1. Belum terdapat penghitung otomatis stok barang dan stok obat.

2. Data produksi yang di-input-kan berdasarkan dari nomor kandang atau nama kandang.

3. Jika terdapat kesalahan input pada pesan yang dikirim oleh pelanggan, maka, admin atau manager tidak dapat membalas pesan tersebut.

4. Notifikasi pemberitahuan pesan baru yang dikirim oleh pelanggan atau masyarakat hanya dapat dilihat jika mengakses halaman Home Admin. 


\section{SIMPULAN DAN SARAN}

\subsection{Simpulan}

Berdasarkan pengujian dari system informasi berbasis web ini, dihasilkan beberapa kesimpulan yang merupakan solusi dari kendala yang terdapat pada proses pengolahan dan pelaporan data pada system Informasi Produksi Berbasis Web Pada CV. Sumber Proteina Bandar Lampung. Berikut kesimpulan dari hasil penelitian, antara lain:

1. Sistem ini menghemat waktu dalam pengiriman laporan, karena laporan yang telah di-input-kan oleh karyawan di bagian kandang, langsung dapat diakses oleh karyawan kantor dan manager.

2. Sistem ini mempermudah karyawan kandang dalam pembuatan laporan, karena data yang diinput-kan akan diolah oleh website.

3. Sistem ini mempermudah masyarakat untuk mendapatkan informasi mengenai informasi produk di CV. Sumber Proteina, karena informasi produk dapat diakses secara online melalui website.

4. Sistem ini mempermudah masyarakat untuk melakukan pemesanan telur melalui website, karena pelanggan atau masyarakat dapat mengirim pesan pada admin melalui layanan contact.

\subsection{Saran}

$\begin{array}{rrr}\text { Berdasarkan } & \text { hal-hal yang } \\ \text { dikemukakan } & \text { diatas, } & \text { untuk }\end{array}$
meningkatkan kualitas Pengelolaan Data Produksi Berbasis Web Pada CV. Sumber Proteina Bandar Lampung yang dibuat maka diberikan saran-saran sebagai berikut :

1. Sistem yang telah dirancang saat ini diharapkan dapat terus di evaluasi, sehingga sistem dapat memberikan pelayanan yang lebih baik lagi.

2. Menambahkan fitur manipulasi data seperti halnya update dan delete sesuai dengan kebutuhan pengguna.

\section{DAFTAR PUSTAKA}

[1] A. Haidar Mirza, U. Ependi, and F. Panjaitan, "Rekayasa Perangkat Lunak Informasi Kemiskinan," J. Inform., vol. 10, no. 1, pp. 11891198, 2016, doi: 10.26555/jifo.v10i1.a3351.

[2] T. Zaini, "Implementasi Metode 
Basisdata Terdistribusi Untuk

Pengelolaan Data Perpustakaan

Berbasis Web," J. Inform.

Darmajaya, vol. 10, no. 1, pp. 1023, 2010.

[3] T. Sutarbi, Konsep Sistem Informasi. 2012.

[4] A. H. Mirza, "Perancangan Basis Data Terdistribusi E-CARGO (Studi Kasus PT. XYZ),” Semin. Nas. Inform. Yogyakarta, vol. 2012, no. semnasIF 2012, pp. 1979-2328, 2012.

[5] A. A. Pradipta, Y. A. Prasetyo, and N. Ambarsari, "Pengembangan Web E-Commerce Bojana Sari Menggunakan Metode Prototype," eProceedings Eng., vol. 2, no. 1, pp. 1042-1056, 2015.

[6] Suendri, "Implementasi Diagram UML (Unified Modelling Language) Pada Perancangan Sistem Informasi Remunerasi
Dosen Dengan Database Oracle (Studi Kasus: UIN Sumatera Utara Medan)," J. Ilmu Komput. dan Inform., vol. 3, no. 1, pp. 1-9, 2018, [Online]. Available: http://jurnal.uinsu.ac.id/index.php/ algoritma/article/download/3148/1 871.

[7] W. Wibisono and F. Baskoro, "Pengujian Perangkat Lunak Dengan Menggunakan Model Behaviour Uml," JUTI J. Ilm. Teknol. Inf., vol. 1, no. 1, p. 43, 2002 , doi: 10.12962/j24068535.v1i1.a95.

[8] Ardiansyah, R. (2019, November). Penggunaan Metode Balance Scorecard Untuk Mengukur Kinerja Pekerjaan Pada PT. Bangun Cipta Karya Pamungkas (PT. BCKP). In Prosiding Seminar Nasional Darmajaya (Vol. 1, pp. 78-87). 